\title{
Valuing multiple forest outputs
}

\author{
by V. A. Lantz 1
}

\begin{abstract}
In today's society, there is increasing pressure placed on forests to provide multiple forest outputs. Forestry organizations have responded by promoting identification and valuation of these outputs for trade-off, criteria and indicators, or other analyses. However, in the process of conducting such analyses, many forest outputs are dropped at the evaluation stage owing to a stated lack of available and reliable data. In an effort to help increase our understanding of the value of multiple forest outputs and trade-offs, I have been refining and applying a number of socio-economic measurement tools. In this article, I provide an overview of my (and my students') research activities and contributions to this growing area of research.
\end{abstract}

Key words: non-market valuation, market valuation, forest value trade-offs, criteria and indicators

\section{RÉSUMÉ}

Des pressions de plus en plus croissantes sont exercées par la société actuelle sur les forêts afin quelles fournissent de multiples produits forestiers. Les organisations oeuvrant en foresterie ont réagi en faisant la promotion de l'identification et de la mise en valeur de ses produits en terme de valeur de remplacement, de critères et d'indicateurs et autres analyses. Toutefois, au cours de ces analyses, plusieurs produits forestiers sont exclus à létape de lévaluation par suite d'une absence déclarée de données disponibles et fiables. Dans un effort d’aider à accroître notre compréhension de la valeur des nombreux produits forestiers et de leur emplacement, jai raffiné et utilisé plusieurs outils de mesures socio-économiques. Dans cet article, je présente un survol de mes activités de recherche et (et de celles de mes étudiants) ainsi que de mes contributions à ce domaine de recherche en croissance.

Mots-clés : valeur non commerciale, valeur commerciale, valeur de remplacement des produits forestiers, critères et indicateurs

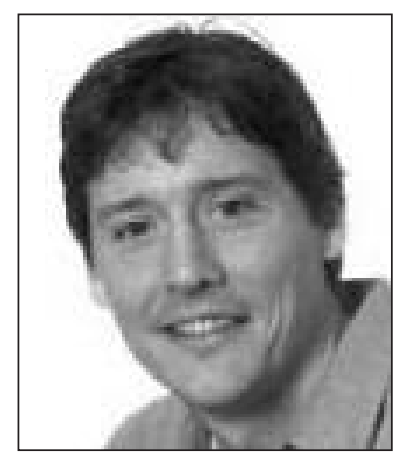

\section{A. Lantz}

\section{Introduction}

Throughout history, forests have provided a wide array of goods and services to society. During World War I, forests provided high-quality timber for British ship masts. Continued industrialization and development in North America brought about a significant demand for lumber and pulp products. As societies have developed in recent times, there has been increasing pressure placed on forests to provide multiple forest outputs (Erdle 1998). The values associated with these multiple outputs have been classified by economists into four categories that include direct-use, indirect-use, option, and non-use values. Directuse values include those associated with timber and non-timber (e.g., maple syrup) forest products, recreation, scenic views, and others directly used in some way by individuals. Indirect-use values include those associated with water quality, erosion control, carbon storage, and others that depend in some way on the state of the forest. Option values are associated with the availability of using outputs produced by forests in the future even if they are not being used presently. Finally, non-use values include those associated with wildlife habitat, biodiversity, spirituality, culture, bequests, and others that the forest provides for the benefit of individuals just through the knowledge that they exist (Pearce 2001).

As public pressure to provide multiple forest outputs intensifies, governments, non-governmental organizations, and private entities are becoming increasingly interested in understanding the full range of values and trade-offs that exist among forest outputs under different forest management decisions (Maness 2007). For instance, a number of organizations such as the Canadian Council of Forest Ministers (CCFM), the Canadian Model Forest Network, and forest certification schemes such as the Forest Stewardship Council have established sustainable forest management criteria and indicator frameworks where the full range of socio-economic values is identified. Others have identified the full range of forest values for use in full cost-benefit analysis of policies, natural capital valuation, genuine progress indicators, and green national accounting (McComb et al. 2006). More than often, however, many of the socio-economic forest outputs are omitted from the analysis at the evaluation stage owing to a lack of available and reliable value data (Adamowicz and Veeman 1998, CCFM 2003, Bull et al. 2007).

Lack of forest value data is not a result of a deficiency in available measurement tools. On the contrary, there exist a large number of socio-economic valuation tools capable of

\footnotetext{
${ }^{1}$ Associate Professor, Faculty of Forestry and Environmental Management, University of New Brunswick, P.O. Box 44555, Fredericton, New Brunswick E3B 6C2. E-mail: vlantz@unb.ca
} 
measuring a wide array of forest outputs. For instance, traditional tools such as market price, production function, and avoided expenditure techniques can be used to measure direct-use and indirect-use values that have observed market prices associated with them. Additionally, more recently developed tools such as the travel cost method, the hedonic pricing method, the contingent valuation method, the choice experiment method, and the benefit transfer method can be used to measure many direct-use, indirect-use, and non-use values that do not have established market prices (Secretariat of the Convention on Biological Diversity 2001). Applications of these tools for measuring forest and other environmental values have increased remarkably throughout the world over the past forty years (Adamowicz 2004). However, their use in Canada has been lacking (van Kooten 1995, Bergstrom and De Civita 1999).

So, if measurement tools exist for the wide array of market and non-market forest values, why does there exist a lack of forest value data needed to conduct forest management tradeoff (and other such) analysis? It turns out that the cause is based on a lack of collection efforts. This lack of effort has arisen from a number of sources that range from limited resources (Turner 2007), to methodological concerns (Adamowicz 2003, 2004; McComb et al. 2006; Bull et al. 2007), to a simple lack of political will (van Kooten 1995, OECD 2007). The CCFM has stated that, unless increased collection efforts are made at many organizational levels, the lack of forest value data will continue (CCFM 2003). Increasing efforts in this area would help improve the selection of economic indicators used in defining sustainable forest management for many organizations (Bull et al. 2007).

In an effort to help increase our understanding of the value of multiple forest outputs and trade-offs in Canada, I have been refining and applying a number of socio-economic measurement tools. In what follows, I provide an overview of my (and my students') research activities and contributions to this growing area of research.

\section{Research Contributions to Valuing Multiple Forest Outputs \\ Market values}

Over the past few years, I have been working with graduate students and other faculty members to examine the value and trade-offs associated with timber production under various policy regimes and landbases across Canada. In a recent project, my Masters of Science in Forestry $(\mathrm{MScF})$ student Mike Kennedy (2003-2006) evaluated forest and economic tradeoffs under alternative forest management strategies on Crown Land in New Brunswick. ${ }^{2}$ For this analysis, we extended a traditional wood supply model to include logging sector profit, government surplus, and gross domestic product (GDP) values (Kennedy et al. 2007b). The research findings revealed that, under a restrictive set of alternative volume- and valuebased strategies, there were significant trade-offs between economic and forest indicators over an 80-year planning horizon. This project was one of the first to fully integrate

${ }^{2}$ David MacLean (UNB) was a co-supervisor and Thom Erdle (UNB) was on the advisory committee for Mr. Kennedy. wood supply modeling with economy-wide impact analysis. We discussed these and other socio-economic issues related to forest management planning in New Brunswick in Kennedy et al. (2007a).

In another timber value analysis, my $\mathrm{MScF}$ student Greg Slaney (2004-present) extended the Spruce Budworm Decision Support System (SBWDSS) developed by MacLean et al. (2001) to include wood product values and protection costs (Slaney et al. 2007). ${ }^{3}$ The extended SBWDSS was used to conduct a cost-benefit analysis of alternative spruce budworm management programs on two case-study regions within New Brunswick and Saskatchewan. The preliminary research findings revealed that, while smaller aerial spray programs targeting the control of spruce budworm outbreaks (such as a 10 000-ha spray program) protected less timber volume and timber (stumpage) value, they provided higher benefit-cost ratios relative to larger protection programs-implying that smaller protection programs are more efficient. This study was the first to extend the SBWDSS to explicitly incorporate economic variables. This framework can be used by forest managers and policy-makers to help make economically efficient pest management decisions.

I have also been involved in developing and applying computable general equilibrium (CGE) models for investigating impacts of forest market and policy changes on GDP, labour income, and employment across Canada. In 2003, I conducted a study with my Masters of Arts student Y. Yigezu (20012002) that examined the economic impacts of timber supply and lumber price reductions on the local economy of the Petiticodiac region in New Brunswick (Lantz and Yigezu 2003). ${ }^{4}$ The results of the analysis revealed that both timber supply and lumber price reductions had significantly negative impacts on output and most production factors in the forest sector. Other production sectors tended to expand as production factors flowed to where they received their highest return. Results of this study indicated that the Petiticodiac region was more significantly impacted by timber supply changes than comparative studies report for other regions in Canada. The opposite was the case for lumber price decreases.

Other CGE studies that I have been involved in consist of analyses of socio-economic transitions in the Foothills Model Forest in Alberta (Patriquin et al. 2007) and pine beetle management in two communities in British Columbia (Patriquin et al. 2008). A CGE study currently under way with my PhD student Thomas Ochuodho (2006-present) will investigate the impacts of various timber supply, tariff, and stumpage

\footnotetext{
${ }^{3}$ This research is funded through a project with the Sustainable Forest Management Network entitled: "Role of pest management in sequestering carbon in the 2008-2012 Kyoto Commitment Period: integration with CBM-CFS2 and economic analyses" (I am the principle investigator and David MacLean (UNB) and Kevin Porter (CFS) are co-investigators). David MacLean (UNB) and Dan Quiring (UNB) are on the advisory committee for Mr. Slaney. ${ }^{4}$ This research was funded through a project with the Fundy Model Forest entitled: "Assessing the importance of market and policy changes in forest communities: A CGE model of a Fundy Model Forest community in New Brunswick" (I was the principle investigator and Derek MacFarlane (CFS) was a co-investigator).
} 
system changes on provincial economies throughout Canada. ${ }^{5}$ This latter initiative will be the first multi-regional analysis of such changes in the forest industry in Canada. Analyses such as these can prove very useful for policy-makers when considering economy-wide impacts of various management decisions in the forest.

A final area of market price analysis in which I have been involved concerns value-added production in the forest industry. In 2004, I conducted a study examining value-added and variable cost trends in five regions and three sectors of the Canadian forest industry over the 1970 to 1995 period (Lantz 2004). Using regression analysis, I found that a number of sectors and regions exhibited favourable value-added and variable cost trends over time. Others, however, did not. To further investigate the determinants of value-added in the various industries, I conducted a study in 2005 that used regression analysis to break down the impacts into operational scale, network scale, prices, and technology effects in five sectors of the Canadian forest industry (see Lantz 2005). Findings revealed that, on average, the first three factors tended to increase value-added production in many sectors while the last factor tended to have the opposite effect. Based on these results, suggestions were made about the manner in which value-added policies could be focused, at a sector-specific level, to realize the full value-added potential that the Canadian forest industry has to offer.

\section{Non-market values}

I have been involved in four major research projects using the contingent valuation method (CVM) over the past few years. In one study, my MScF student Ryan Trenholm (2005-present) employed the CVM to investigate the social benefits and costs of providing riparian areas on private woodlots in the Canaan-Washedemoak watershed of Southern New Brunswick (Lantz et al. 2007). ${ }^{6}$ In the analysis, we asked a random sample of households in southern New Brunswick about their maximum willingness to pay for $30-\mathrm{m}$ and $60-\mathrm{m}$ riparian areas adjacent to waterways in the Canaan-Washedemoak watershed. We also asked approximately one half of all riparian landowners about their minimum willingness to accept compensation for the provision of these areas. We found that $30-\mathrm{m}$ riparian areas generally produced positive net social benefits while $60-\mathrm{m}$ riparian areas did not. Within the analysis we decomposed the total benefits into per-acre benefits for wildlife, forest views, and recreation services.

In a second CVM study, my MScF student Helen Smith (2003-present) investigated the social benefits of maintaining

\footnotetext{
${ }^{5}$ This research is being funded through a project with the Sustainable Forest Management Network entitled: "Economics of Sustainable Forest Management" (Shashi Kant (UofT) is the primary investigator, and Cornelious van Kooten (UofVic), Susanna Laaksonen-Craig (BC Ministry of Forests), and I are co-investigators). Don Floyd (UNB) and Rajendra Chiani (CFS) are on the advisory committee for Mr. Ochuodho.

${ }^{6}$ This research was primarily funded through a project with the Fundy Model Forest and Canada Model Forest Network entitled: "Private Woodlot provision of Public Goods" (I was the principle investigator and Tom Beckley (UNB), Shawn Dalton (UNB), and Glenn Fox (UofG) were co-investigators). Rajendra Chiani (CFS) and Roberto Martinez-Espineira (SFX) are on the advisory committee for Mr. Trenholm.
}

private forest land across the province of New Brunswick (Smith and Lantz 2004). ${ }^{7}$ In the analysis, we asked a random sample of households in New Brunswick about their maximum willingness to pay for a program that would help establish sustainable forest management plans on private woodlots in the province. We found that the general public was willing to pay a significant amount to help maintain the natural state of private forests for maintaining wildlife habitat, forest views, and some (limited) recreational opportunities.

My MScF student Jeff Wilson (2004-present) has just completed a third CVM study on benefits of establishing protected natural areas (PNA) in New Brunswick. ${ }^{8}$ In the analysis, we asked a random sample of households across New Brunswick about their maximum willingness to pay for maintaining the current system of 10 PNAs (representing just over $2 \%$ of forestland in the province). We also asked participants, in a split sample, their maximum willingness to pay for increasing PNAs to $5 \%, 8 \%, 11 \%$, and $14 \%$. We found that the general public was willing to pay a significant amount to help maintain the existing PNAs (i.e., a larger amount than the foregone timber value), and that the public's willingness to pay increased with increasing the percentage of PNAs in the province. These non-market value estimates are being compared to the foregone economic rent from timber harvesting to examine the net benefits of the PNAs in the province.

In the final CVM study, my PhD student Wei-Yew Chang (2005-present) is conducting an examination of social benefits and costs of forest pest outbreaks and control in New Brunswick and Saskatchewan. ${ }^{9}$ In the analysis, we asked a random sample of households in New Brunswick and Saskatchewan about whether or not they supported controlling spruce budworm and forest tent caterpillar outbreaks in their province. If they answered yes, we asked them to state their maximum willingness to pay to help control the next outbreak of each pest. If they answered no, we asked them to state their maximum willingness to pay to compensate others for the losses they would incur from the unprotected outbreak. While, in each province, we found positive net social benefits for controlling both pests, net social benefits were larger for the spruce budworm outbreak indicating that the public is sensitive to the relative impacts of these two very different pests. These non-market value estimates are being incorporated into a full cost-benefit analysis (including both non-market and market values) of pest management in the province.

\footnotetext{
${ }^{7}$ This research was funded through a project with the Fundy Model Forest entitled: "Measuring non-market forest values in new Brunswick" (I was the principle investigator and Solange Nadeau (CFS) was a co-investigator). Tom Beckley (UNB), Solange Nadeau (CFS), and Derek MacFarlane (CFS) are on the advisory committee for Ms. Smith.

${ }^{8}$ David MacLean (UNB) is on the advisory committee of Mr. Wilson. ${ }^{9}$ This research is being funded through a project with the Sustainable Forest Management Network entitled "Role of pest management in sequestering carbon in the 2008-2012 Kyoto Commitment Period: integration with CBM-CFS2 and economic analyses" (I am the principle investigator and David MacLean (UNB) and Kevin Porter (CFS) are co-investigators). Dave MacLean (UNB) and Kevin Porter (CFS) are on the advisory committee of Mr. Chang.
} 


\section{Conclusions}

Lack of value data for many forest outputs has often caused forestry organizations to exclude them from trade-off and other such analysis. Omitting the value of these outputs may seriously limit the ability of managers and policy-makers to make decisions in the best interest of the owners of the forest resource.

Over the past several years, I have been working with graduate students to refine and apply a number of tools used to measure the value of multiple forest outputs on specific landbases in Canada. These methods used can be applied to other landbases to help improve assessment of the full range of forest values and trade-offs that exist.

The estimates produced in my research (and those from other forest valuation researchers in Canada) can also be used to value forest outputs on other landbases in Canada through the use of the benefit transfer method. Significant strides have already been made by Environment Canada in using this method to value the health effects of air pollution (Bergstrom and De Civita 1999). Recent efforts by Haener and Adamowicz (2000), Olewiler (2004) and Anielski and Wilson (2005) to value the full range of ecosystem functions provided by forests, watersheds, and wetlands in specific Canadian regions are welcomed initiatives toward valuing the full range of forest and other natural resource outputs. However, broader efforts are urgently needed. Such efforts would surely help create a more sustainable future for forests in Canada.

\section{References}

Adamowicz, W. 2003. Economic indicators of sustainable forest management: theory versus practice. J. For. Econ. 9 (27): 27-40.

Adamowicz, W. 2004. What's it worth? An examination of historical trends and future directions in environmental valuation. Aust. J. Agric. and Resour. Econ. 48: 419-443.

Adamowicz, W. and T. Veeman. 1998. Forest policy and the environment: changing paradigms. Canadian Public Policy XXIV (Supplement 2): 51-61.

Anielski, M. and S. Wilson. 2005. Counting Canada's natural capital: Assessing the real value of Canada's boreal ecosystems. Report prepared for the Pembina Institute. 78p.

Bergstrom, J.C. and P. De Civita. 1999. Status of benefits transfer in the United States and Canada: A review. Can. J. Agric. Econ. 47: 79-87. Bull, G., O. Schwab and P. Jayasinghe. 2007. Economic indicators and their use in sustainable forest management. BC J. Ecosyst. Manage. 8(2): 37-45.

Canadian Council of Forest Ministers (CCFM). 2003. Defining sustainable forest management in Canada: Criteria and Indicators 2003. Technical Supplement 1: Detailed Indicator Descriptions. Canadian Council of Forest Ministers, Ottawa, ON., Ottawa, Ont. Available at www.ccfm.org/current/ccitf_e.php [Accessed: Dec. 10, 2007].

Erdle, T. 1998. Progress towards sustainable forest management: insight from the New Brunswick experience. For. Chron. 74: 378-384. Haener, M. and W. Adamowicz. 2000. Regional forest resource accounting: a northern Alberta case study. Can. J. For. Res. 30: 264-273.
Kennedy, M., T. Beckley and V. Lantz. 2007a. Expanding socioeconomic considerations in the management of New Brunswick's Crown Land forests. For. Chron. 83: 708-713.

Kennedy, M., V. Lantz and D. MacLean. 2007b. Forest and economic impacts of alternative management strategies on Crown land in New Brunswick. Can. J. For. Res. 37(12): 2624-2636.

Lantz, V. 2004. An examination of value-added and variable cost trends across Canadian forest regions and sectors. For. Chron. 80: 718-726.

Lantz, V. 2005. Measuring scale, technology, and price impacts on value-added across Canadian forest industry sectors. For. Policy Econ. 7: 333-344.

Lantz, V., T. Beckley, S. Dalton, G. Fox, M. Klimas, S. Little, S. Merrill and R. Trenholm. 2007. Valuing the contribution of private woodlots to society: a focus on riparian areas in a New Brunswick watershed. Research Report prepared for the Fundy Model Forest and Canadian Model Forest Network. 100 p.

Lantz, V. and Y. Yigezu. 2003. An economic impact analysis of market and policy changes in a New Brunswick Fundy Model Forest community. For. Chron. 79: 957-966.

MacLean, D.A., T.A. Erdle, W.E. MacKinnon, K.B. Porter, K.P. Beaton, G. Cormier, S. Morehouse and M. Budd. 2001. The Spruce Budworm Decision Support System: forest protection planning to sustain long-term wood supplies. Can. J. For. Res. 31: 1742-1757.

Maness, T. 2007. Trade-off analysis for decision making in natural resources: Where we are and where we are headed. BC J. Ecosyst. Manage. 8 (2): 1-16.

McComb, G., V. Lantz, R. Rittmaster and K. Nash. 2006. International Valuation Databases: Overview, Methods and Operational Issues. Ecol. Econ. 60: 461-472.

Organization for Economic Co-operation and Development (OECD). 2007. Assessing environmental policies. Policy Brief. Available at http://www.oecd.org/dataoecd/52/15/38208236.pdf [Accessed: Jan. 10, 2008].

Olewiler, N. 2004. The value of natural capital in settled areas of Canada. Report prepared for Ducks Unlimited Canada and the Nature Conservancy of Canada. $36 \mathrm{p}$.

Patriquin, M., R. Furtas, M. Ambard, W. White and V. Lantz. 2007. Socio-economic transition in the Foothills Model Forest: 1996 to 2001. Information Report NOR-X-410, Canadian Forest Service. 33 p. Patriquin, M.N., V.A. Lantz, R.C. Stedman and W.A. White. 2008. Working together: A reciprocal wood flow arrangement to mitigate the economic impacts of natural disturbance. Forestry: Int. J. For. Res. 81(2): 227-242.

Pearce, D. 2001. The economic value of forest ecosystems. Ecosyst. Health 7: 284-296.

Secretariat of the Convention on Biological Diversity. 2001. The value of forest ecosystems. CBD Technical Series No. 4. Montreal. $67 \mathrm{p}$. Slaney, G., D. MacLean, V. Lantz and K. Porter. 2007. Cost effectiveness of pest management investments: expanding PROPS to include costs, product value and carbon. Technical Note prepared for the Spray Efficacy Research Group International (SERG-I). 15 p. Smith, H. and V. Lantz. 2004. Examining public opinion on forest values and management: NB forest values survey. Research Report prepared for the Fundy Model Forest (FMF), Sussex, NB. 33 p.

Turner, R. 2007. Limits to CBA in UK and European environmental policy: retrospects and future prospects. Environ. Resour. Econ. 37: 253-269.

van Kooten, G. 1995. Can nonmarket values be used as indicators of forest sustainability? For. Chron. 71: 702-711. 